\title{
Population size and status of the Yellow-breasted Racquet-tail Parrot Prioniturus flavicans
}

JONATHAN S. WALKER and ALEXIS J. CAHILL

\begin{abstract}
Summary
Densities and population estimates are presented for the little known Yellow-breasted Racquet-tail Parrot Prioniturus flavicans, a species endemic to the Indonesian island of Sulawesi. Sixteen months of fieldwork was conducted within two protected areas in the island's northern peninsula. Densities were found to be much greater in the Bogani Nani Wartabone National Park than in the Tangkoko Duasaudara Nature Reserve: 16.27 and 7.18 birds $/ \mathrm{km}^{2}$, respectively. The species has a much more restricted range than previously thought, being confined to the eastern two-thirds of the north peninsula. The remaining suitable habitat within this range, lowland rainforest, is estimated to be c. $11,300 \mathrm{~km}^{2}$. Using this figure in conjunction with density values we estimate that the world population for this species may be greater than 44,650 birds. Whilst such a population size is higher than previously thought, the very restricted distribution of the species causes concern for its future as loss and fragmentation of forest habitat are ongoing within its range.
\end{abstract}

\section{Introduction}

The Racquet-tail Parrots Prioniturus are one of the most globally threatened parrot taxa. Occurring only in the Philippine and Indonesian archipelagos, nine species are generally recognized (Juniper and Parr 1998, del Hoyo et al. 1997, but see Inskipp et al. 1996). One species is classified as "endangered", two are "vulnerable" and a further four are "near-threatened" (Collar et al. 1994, 1998).

The primary threat to most Racquet-tail Parrot species is the loss of their forest habitat. Olsen and Dinerstein (1998) classify Philippine moist forests as "critically endangered", which is reflected in that the "endangered" and "vulnerable" species are all Philippine species. Within Indonesia, one Racquet-tail Parrot species is endemic to the Moluccan Island of Buru, whilst two species occur on the island of Sulawesi, where they are largely sympatric. Despite continuing loss, degradation and fragmentation, the moist forest habitats of Racquet-tail Parrots in the Moluccas and Sulawesi are considered relatively stable (Olson and Dinerstein 1998) with Indonesian Racquet-tail Parrots not currently facing the same level of threat risk as their Philippine congeners. On Sulawesi, the Golden-mantled Racquet-tail Parrot Prioniturus platurus, is not classified as "threatened"; however, the more restricted-range Yellow-breasted Racquet-tail Parrot P. flavicans, which is confined to northern Sulawesi (Forshaw 1989, Coates and Bishop 1997), is currently classified as "near threatened" (Collar et al. 1994). 
The Yellow-breasted Racquet-tail Parrot is primarily found in the lowlands between sea level and $650 \mathrm{~m}$ but has been recorded as high as 1,000 $\mathrm{m}$ (Coates and Bishop 1997, Forshaw 1989). It is a forest species for which, as with its congeners, very few behavioural or ecological data have been collected (but see Coates and Bishop 1997, Watling 1983). In this paper we present data on population densities, a world population estimate and assess the implications of our findings for the current threat status of the species.

\section{Study areas and methods}

The study was carried out in two protected areas in north Sulawesi, Indonesia, over a two-year period beginning in October 1996. The first year of fieldwork was in the Tangkoko-Duasaudara Nature Reserve (Tangkoko) located at the eastern tip of the northern peninsula, $1^{\circ} 34^{\prime} \mathrm{N}, 125^{\circ} 14^{\prime} \mathrm{E}$. The predominant habitat in this $88.8 \mathrm{~km}^{2}$ reserve is lowland rain forest in which data collection was undertaken within a study site on foot slopes of the Tangkoko volcano of altitudinal range $\mathrm{o}-300 \mathrm{~m}$. The second year of fieldwork was conducted in the Bogani Nani Wartabone National Park (BNW) - formerly the Dumoga Bone National Park situated in the centre of the island's north peninsula, $\mathrm{O}^{\circ} 34^{\prime} \mathrm{N}, 123^{\circ} 53^{\prime} \mathrm{E}$. Approximately $70 \%$ of this $2,870 \mathrm{~km}^{2}$ park is classified as lowland rainforest (Rodenburg and Palete 1981), most of which is hill-forest. Data collection was conducted in a lowland rainforest study site called Toraut, at an altitudinal range of $200-400 \mathrm{~m}$.

A point count distance sampling method (Buckland et al. 1993) was used to collect data for the production of density estimates. Surveys were carried out between 06 hoo and oghoo on a weekly basis from 60 points at Tangkoko and 30 points at BNW. During six consecutive months of fieldwork at Tangkoko 1219 point counts were conducted. At BNW, 10 consecutive months of fieldwork and 950 point counts were conducted. Data were analysed using DISTANCE software (Thomas et al. 1998).

Population estimates for each site were calculated by multiplying density estimates by the area of lowland rainforest cover at the site. World population estimates were produced by multiplying density estimates by the area of remaining lowland rainforest cover within the species range.

\section{Results}

Some discrepancy has occurred in the literature over the exact distribution of the Yellow-breasted Racquet-tail Parrot. Recent published accounts state that the Yellow-breasted Racquet-tail Parrot occurs only in the northern peninsula (Coates and Bishop 1997) or conversely that it extents further south into northcentral Sulawesi (White and Bruce 1986, Forshaw 1989, Juniper and Parr 1998, del Hoyo et al. 1997) - see Figure 1. We are not aware of any recent records of the species in the Lore Lindu National park, where, if the species does exist in north-central Sulawesi, it is almost certain to occur. During the course of extensive fieldwork in the Lore Lindu area (1981-1999), K.D. Bishop (in litt.) has never encountered this species, nor has D. Holmes (in litt.) recorded it during his visits to the western side of the north peninsula. Indeed, K.D. Bishop (in litt.) has reviewed the literature and collection sites of specimens held at several museums 


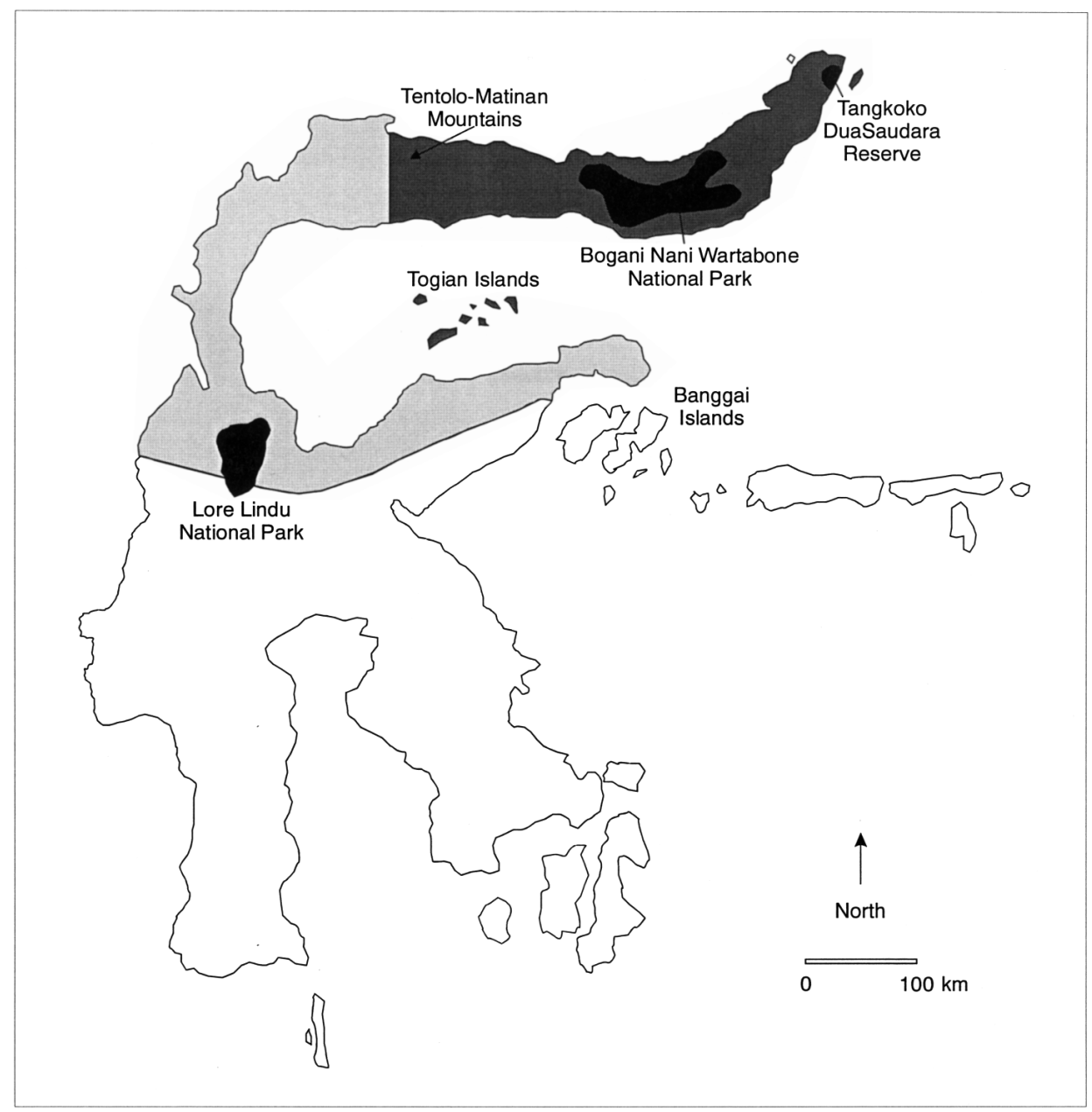

Figure 1. Map of Sulawesi showing the previously accepted range of the Yellow-breasted Racquet-tail Parrot (entire shaded area) and the revised range followed in this paper (dark grey shading only). Black represents protected areas.

and has found no record of this species further west in the north peninsula than that near Paleleh/the Tentolo-Matinan Mountains by G. Heinrich (in Stresemann 1939). Furthermore, D. Holmes (in litt.) states that flocks seen on Banggai as reported by Indrawan et al. (1997) were never fully verified. From these data, it would appear that the Yellow-breasted Racquet-tail Parrot might actually have a much more restricted distribution than previously thought, being recorded only from the eastern two-thirds of the north peninsula (Figure 1).

Based on this information, we calculated the total lowland rainforest cover within the species' range from data compiled by the World Conservation Monitoring Centre (WCMC 1999). We estimate that $c .11,300 \mathrm{~km}^{2}$ of lowland rainforest remains within the Yellow-breasted Racquet-tail Parrot's range. This figure was 
Table 1. Density and population estimates for the Yellow-breasted Racquet-tail Parrot at two sites in north Sulawesi (Tangkoko and BNW), and their extrapolation to produce world population estimates. Average values of both sites were calculated by taking the mean of BNW and Tangkoko results. Mean population estimates are quoted with 95\% C.I. in parentheses. Estimates for Tangkoko are rounded to the nearest $10, \mathrm{BNW}$ and world estimates to the nearest 50

\begin{tabular}{|c|c|c|c|c|c|c|}
\hline \multirow[t]{2}{*}{ Site } & \multirow{2}{*}{$\begin{array}{c}\text { Con- } \\
\text { tacts } \\
(n)\end{array}$} & \multirow{2}{*}{$\begin{array}{r}\text { Density } \\
\left(\mathrm{km}^{2}\right)\end{array}$} & \multirow[t]{2}{*}{ S.E. } & \multicolumn{3}{|c|}{ Population estimate (birds $/ \mathrm{km}^{2}$ ) } \\
\hline & & & & Tangkoko & $\mathrm{BNW}$ & World \\
\hline BNW & 222 & 16.27 & 1.69 & - & $\begin{array}{l}30,900 \\
(24,600-37,200)\end{array}$ & $\begin{array}{l}183,850 \\
(146,450-221,250)\end{array}$ \\
\hline Tangkoko & 70 & $7 \cdot 18$ & 1.65 & $430(240-630)$ & - & $81,150(44,650-117,650)$ \\
\hline $\begin{array}{l}\text { Mean of } \\
\text { both sites }\end{array}$ & - & 11.73 & - & $700(510-900)$ & $\begin{array}{l}22,300 \\
(16,050-28,500)\end{array}$ & $\begin{array}{l}132,500 \\
(95,550-169,450)\end{array}$ \\
\hline
\end{tabular}

subsequently used in the production of the world population estimate for the species. Within the two protected areas, we estimate the cover of lowland rainforest to be c. $60 \mathrm{~km}^{2}$ in Tangkoko (calculated from Kinnaird and $\mathrm{O}^{\prime} B r i e n$ 1995) and c. $1,900 \mathrm{~km}^{2}$ in BNW (calculated from PHPA 1995).

The density estimate for BNW is considerably higher than the estimate for the Tangkoko Duasaudara Nature Reserve, see Table 1 for density and population size estimates. Using the more conservative density estimate obtained for Tangkoko, the lower $95 \%$ C.I. indicates the world population size of the Yellowbreasted Racquet-tail Parrot may be upwards of 44,650 birds.

During fieldwork at BNW, 6o visual observations were made of Yellowbreasted Racquet-tail Parrot groups feeding. Of these, 37\% were of single birds, $32 \%$ pairs and $17 \%$ groups of three birds. Flocks of more than three birds made up less than $15 \%$ of observations with six birds comprising the largest flock observed.

\section{Discussion}

Previous observations that Yellow-breasted Racquet-tail Parrots are particularly common at BNW (Coates and Bishop 1997) are supported by our density estimates. However, we were unable to determine whether the high density found at Toraut is found throughout the entire park. Reasons why BNW supports higher densities than Tangkoko are unknown. There are, however, distinct differences in rainfall, floristic composition and structure of the forest between the sites (pers. obs.).

Coates and Bishop (1997) describe the species as uncommon with a patchy distribution, although locally it can be moderately common or absent. The densities that are supported in protected areas other than BNW and Tangkoko are unknown. We have assumed that our estimates are representative of the entire range and that the species is primarily confined to lowland forest. In light of such assumptions we have presented as full a picture as possible on Yellow-breasted Racquet-tail Parrot densities and population sizes.

There have been no previous population estimates for the Yellow-breasted Racquet-tail Parrot derived from systematic surveys. The figure quoted by Juni- 
per and Parr (1998) of below 10,00o birds would appear to underestimate this species's true abundance. The population of the Buru Racquet-tail Parrot P. mada has also been underestimated; Marsden et al. (1997) recently published a world population estimate for this "near threatened" species (Collar et al. 1994) of greater than 147,000 birds. The Buru Racquet-tail Parrot forms large flocks of up to 55 birds (Marsden 1995) and occurs at high densities, 23.7-87.9 birds $/ \mathrm{km}^{2}$ in primary/secondary forest and $84.1-247.9$ birds $/ \mathrm{km}^{2}$ in logged forest (Marsden et al. 1997). Poulsen (1998) recorded densities for the same species of 39.7-183 birds $/ \mathrm{km}^{2}$ in primary forest and $10.6-65.9 \mathrm{birds} / \mathrm{km}^{2}$ in modified forest. Unlike the Buru Racquet-tail Parrot, the Yellow-breasted Racquet-tail Parrot was only found to occur at low densities and was only ever seen to form small flocks.

A minimum population size of 44,650 individuals would mean the Yellowbreasted Racquet-tail Parrot is more common that previously thought. From information currently available, the species appears to have a very restricted range of only c. $11,300 \mathrm{~km}^{2}$. Loss, degradation and fragmentation of its forest habitat are continuing at high rates throughout the peninsula, especially within the range of the species and even within protected areas (pers. obs.). With a range smaller than $20,000 \mathrm{~km}^{2}$ and habitat loss ongoing within this range, the Yellow-breasted Racquet-tail Parrot qualifies for the "vulnerable" category of threat (Mace and Stuart 1994).

We have produced a "ball park" world population estimate in light of little being known about this rare species. Further fieldwork in the western side of the north peninsula is needed to determine more exactly the distribution of the species. Even if new localities in the north peninsula are found, the species will still have a very small range as, from our estimation, less than $20,000 \mathrm{~km}^{2}$ of lowland rainforest remain within the entire north peninsula. Overall, the findings present new data to the small body of ecological information that exists on racquet-tail parrots and reaffirm the need for greater protection of tropical forests both in Indonesia and the Philippines to ensure the future security of these parrots.

\section{Acknowledgements}

We thank the Indonesian Institute of Sciences (LIPI), the Directorate General for Nature Preservation and Forest Protection (PHPA) and head of BNW, D. Nurhadi, for their sponsorship and permissions to carry out the research. Special thanks go to the directors of WCS-IP, Drs Margaret Kinnaird and Timothy $\mathrm{O}^{\prime}$ Brien, for their support, advice and encouragement throughout our research. David Bishop and Derek Holmes are thanked for information and advice on the distributional range. Rory Putman, Martin Jones and Stuart Marsden are thanked for commenting on the manuscript. Funding for this project was provided by the Wildlife Conservation Society, the Royal Geographical Society, Chester Zoological Gardens and the Rhode Island Zoological Society.

\section{References}

Buckland, S.T., Anderson, D.R., Burnham, K.P. and Laake, J.L. (1993) Distance sampling: estimating abundance of biological populations. London: Chapman and Hall. 
Coates, B.J. and Bishop, K.D. (1997) A guide to the birds of Wallacea. Sulawesi, the Moluccas and lesser Sunda Islands, Indonesia. Aderley, Australia: Dove Publications.

Collar, N.J., Crosby, M.J. and Stattersfield, A.J. (1994) Birds to watch 2: the World List of Threatened Birds. Cambridge, U.K.: Birdlife International (Conservation Series 4).

Collar, N.J., Tabaranza, B.R. and Mallari, N.A.D. (1998) Threatened birds of the Philippines. Manila: Bookmark.

del Hoyo, J., Elliot, A. and Sargatal, J., eds. (1997) Handbook of the birds of the world, 4. Sandgrouse to cuckoos. Barcelona: Lynx Edicions.

Forshaw, J.M. (1989) Parrots of the world. Third edition. Melbourne: Landesdowne Editions.

Indrawan, M., Masala, Y. and Pesik, L. (1997) Recent observations from the Banggai Islands. Kukila 9: 61-70.

Inskipp, T., Lindsey, N. and Duckworth, W. (1996) An annotated checklist of the birds of the Oriental region. Sandy, U.K.: Oriental Bird Club.

Juniper, T. and Parr, M. (1998) Parrots: a guide to the parrots of the world. Robertsbridge, U.K.: Pica Press.

Kinnaird, M.F. and O'Brien, T. G. (1995) Tangkoko-Duasaudara Nature Reserve, North Sulawesi, Draft Management Plan: 1996-200o. Bogor, Indonesia: Wildlife Conservation Society report to the Directorate of Nature Conservation, Indonesia.

Mace, G. and Stuart, S. (1994) Draft IUCN red list categories, version 2.2. Species 21/22: 13-24. Gland, Switzerland: IUCN.

Marsden, S.J. (1995) The ecology and conservation of the parrots of Sumba, Buru and Seram, Indonesia. Unpublished PhD thesis. Manchester Metropolitan University, U.K.

Marsden, S.J., Jones, M.J., Linsley, M.D., Mead, C. and Hounsome, M.V. (1997) The conservation status of the restricted-range lowland birds of Buru, Indonesia. Bird Conserv. Internatn. 7: 213-233.

Olson, D.M. and Dinerstein, E. (1998) The global 200: a representation approach to conserving the earth's most biologically valuable ecoregions. Washington, D.C.: World Wildlife Fund US.

PHPA (1995) Rencana Pengelolaan Taman Nasional Bogani Nani Wartabone: 1995-2020. Buku II. Kotomobagu, Sulut: Deptartemen Kehutanan.

Poulsen, M.K. (1998) Prioritas Konservasi Keragaman Hayati di Pulau Buru: dengan acuan khusus tentang usulan Suaka Margasatwa Kapalat Mada. Bogor, Indonesia: PHPA/BirdLife International. Laporan 8.

Rodenburg, W.F. and Palete, R. (1981) Proposed Dumoga-Bone National Park, North Sulawesi, Indonesia. Management Plan 1982-1983. Bogor, Indonesia: WWF report to Directorate of Nature Conservation, Indonesia.

Stresemann, E. (1939) Die Vögel von Celebes, Parts I and II. Biologische Beiträge von Gerd Heinrich. J. Orn. 87: 299-425.

Thomas, L., Laake, J.L., Derry, J.F., Buckland, S.T., Borchers, D.L., Anderson, D.R., Burnham, K.P., Strindberg, S., Hedley, S.L., Burt, M.L., Marques, F., Pollard, J.H. and Fewster, R.M. (1998) Distance 3.5. Research Unit for Wildlife Population Assessment. University of St. Andrews, U.K.

Watling, D. (1983) Ornithological notes from Sulawesi. Emu 83: 247-261.

WCMC (1999) Forest cover in eastern Indonesia showing the island of Sulawesi and sustainable forest area. Cambridge, U.K.: World Conservation Monitoring Centre.

White, C.M.N. and Bruce, M.D. (1986) The birds of Wallacea (Sulawesi, the Molluccas and Lesser Sunda Islands, Indonesia). London: British Ornithologists Union (Checklist 7).

JONATHAN S. WALKER and ALEXIS J. CAHILL

Behavioural and Environmental Biology Group, Department of Biological Sciences, Manchester Metropolitan University, Chester Street, Manchester M1 5GD, U.K. 